population for prevention of cardiovascular disease until their benefit is proved by controlled clinical trials.

We thank the Busselton Population Medical Research Foundation for access to the Busselton health survey data and the Busselton community for their longstanding cooperation and support for the Busselton health study.

Contributors: See bmj.com

Funding: None.

Competing interests: None declared.

1 Boushey CJ, Beresford SA, Omenn GS, Motulsky AG. A quantitative assessment of plasma homocysteine as a risk factor for vascular disease. Probable benefits of increasing folic acid intakes. JAMA 1995;274:104957.

2 Eikelboom JW, Lonn E, Genest J Jr, Hankey G, Yusuf S. Homocyst(e)ine and cardiovascular disease: a critical review of the epidemiologic evidence. Ann Intern Med 1999;131:363-75

3 Selhub J, Jacques PF, Wilson PW, Rush D, Rosenberg IH. Vitamin status and intake as primary determinants of homocysteinemia in an elderly population. JAMA 1993;270:2693-8.

4 Ubbink JB. Vitamin nutrition status and homocysteine: an atherogenic risk factor. Nutr Rev 1994;52:383-7.

5 Homocysteine Lowering Trialists' Collaboration. Lowering blood homocysteine with folic acid based supplements: meta-analysis of randomised trials. BMJ 1998;316:894-8.

6 Morrison HI, Schaubel D, Desmeules M, Wigle DT. Serum folate and risk of fatal coronary heart disease. JAMA 1996;275:1893-6.

7 Chasan-Taber L, Selhub J, Rosenberg IH, Malinow MR, Terry P, Tishler $\mathrm{PV}$, et al. A prospective study of folate and vitamin $\mathrm{B} 6$ and risk of infarction in US physicians. J Am Coll Nutr 1996:15:136-42.

8 Folsom AR, Nieto FJ, McGovern PG, Tsai MY, Malinow MR, Eckfeldt JH, et al. Prospective study of coronary heart disease incidence in relation to fasting total homocysteine, related genetic polymorphisms, and $\mathrm{B}$ vitamins: the atherosclerosis risk in communities (ARIC) study. Circulation 1998;98:204-10.

9 Ford ES, Byers TE, Giles WH. Serum folate and chronic disease risk: findings from a cohort of United States adults. Int J Epidemiol 1998;27:592-8.

10 Rimm EB, Willett WC, Hu FB, Sampson L, Colditz GA, Manson JE, et al. Folate and vitamin B6 from diet and supplements in relation to risk of coronary heart disease among women. JAMA 1998;279:359-64.

11 Voutilainen S, Rissanen TH, Virtanen J, Lakka TA, Salonen JT, Kuopio Ischemic Heart Disease Risk Factor Study Group. Low dietary folate intake is associated with an excess incidence of acute coronary events. Circulation 2001;103:2674-80.

12 Cullen KJ. Mass health examinations in the Busselton population, 1966 to 1970. Med J Aust 1972;2:714-8.

13 Knuiman MW, Jamrozik K, Welborn TA, Bulsara MK, Divitini ML, Whittall DE. Age and secular trends in risk factors for cardiovascular disease in Busselton. Aust J Public Health 1995; 19:375-82.

14 Knuiman MW, Vu HT, Bartholomew HC. Multivariate risk estimation for coronary heart disease: the Busselton health study. Aust NZJ Public Health 1998;22:747-53.

15 Knuiman MW, Vu HT. Risk factors for stroke mortality in men and women: The Busselton study. J Cardiovasc Risk 1996;3:447-52.

16 Knuiman MW, Vu HT. Prediction of coronary heart disease mortality in Busselton, Western Australia: an evaluation of the Framingham, national health epidemiologic follow up study, and WHO ERICA risk scores. $J$ Epidemiol Commun Health 1997;51:515-9.

17 Davis RE. Serum vitamin levels and human nutrition. Proc Nutr Soc Aust 1979;4:45-52.

18 Babior BM. The megaloblastic anemias. In: Beutler E, Lichtman M, Coller B, Kipps T, Seligsohn U, eds. Williams hematology. 6th ed. Chicago: McGraw-Hill, 2001:425-45.

19 Malinow MR, Bostom AG, Krauss RM. Homocyst(e)ine, diet, and cardiovascular diseases: a statement for healthcare professionals from the nutrition committee, American Heart Association. Circulation 1999;99:178-82.

(Accepted 26 September 2002)

\title{
Impact of changing diagnostic criteria on incidence, management, and outcome of acute myocardial infarction: retrospective cohort study
}

\author{
J P Pell, E Simpson, J C Rodger, A Finlayson, D Clark, J Anderson, A C H Pell
}

Department of

Medicine,

Monklands

Hospital, Airdrie

Lanarkshire

ML6 0JS

A C H Pell

consultant

cardiologist

J C Rodger

consultant

cardiologist

J Anderson

research assistant

Department of

Biochemistry,

Monklands

Hospital

E Simpson

consultant clinical

scientist

Department of

Public Health,

Greater Glasgow

NHS Board,

Glasgow

J P Pell

consultant in public

health medicine

continued over

BMJ 2003;326:134-5
Acute myocardial infarction used to be defined by criteria based on symptoms, changes in electrocardiograms and the concentrations of cardiac enzymes, as recommended by the World Health Organization. ${ }^{1}$ Specific markers of myocardial damage, including troponin $\mathrm{T}$, are more sensitive indicators than total creatine kinase concentration for ischaemic myocardial necrosis and prognosis. ${ }^{2}$

In 2000, the European Society of Cardiology and the American College of Cardiology recommended changing the diagnostic criteria for acute myocardial infarction to include raised troponin $\mathrm{T}$ concentrations in addition to changes in electrocardiograms or coronary intervention. ${ }^{3}$ Some patients with acute coronary syndrome who had been diagnosed as having unstable angina are now classified as having myocardial infarction. We investigated the impact of using the new criteria on the incidence, management, and outcome of myocardial infarction.

\section{Participants, methods, and results}

Since 1997, all patients admitted with chest pain to Monklands Hospital, Airdrie, had their troponin T concentrations measured. We identified patients admitted between April 1997 and December 2000 with a principal diagnosis of acute myocardial infarction, according to the old criteria, from routine discharge data, the databases of the coronary care unit and laboratory, and case notes. We used the databases to identify patients admitted for chest pain who had raised troponin $\mathrm{T}$ concentrations $(\geqslant 0.1 \mathrm{ng} / \mathrm{ml})$ in the absence of non-myocardial causes such as renal failure, thromboembolic disease, or myocarditis. The new criteria increased admissions for myocardial infarction by $58 \%$, from 1671 to 2637 ; this equated to approximately 160000 additional myocardial infarctions per year in the United Kingdom.

Compared with patients who met the old criteria, the additional 966 patients identified were older (median age $74 v 68$ years; $\mathrm{P}<0.001$; Mann Whitney $\mathrm{U}$ test) and a higher proportion were women $(47 \% v$ $38 \% ; \mathrm{P}<0.0001, \chi^{2}$ test). Thrombolysis was given to only 13 of the additional patients compared with 672 patients who met the old criteria ( $1 \%$ v $40 \%$; $\mathrm{P}<0.0001 ; \chi^{2}$ test). As a result, thrombolysis rates fell from $40 \%(95 \%$ confidence interval $38 \%$ to $42 \%)$ to $26 \%(24 \%$ to $28 \%)$.

Linkage to national admission (Scottish morbidity record) and death data (General Registrar's Office) provided information on survival, readmission for ischaemic heart disease, coronary angiography, and coronary revascularisation. We calculated cumulative 
probabilities of these outcomes up to one year of follow up using Kaplan-Meier product limit estimates.

The additional patients had higher 30 day mortality ( $\mathrm{P}=0.016, \log$ rank test) (table). The difference in mortality increased over one year $(\mathrm{P}<0.0001, \log$ rank test). In a Cox proportional hazards model, the difference in survival on univariate analysis (hazard ratio $2.69 ; 2.32$ to 3.12 ) was slightly attenuated after adjustment for age, sex, and deprivation $(2.07 ; 1.77$ to 2.42) and attenuated further after we adjusted for thrombolysis administration $(1.87 ; 1.58$ to 2.20$)$. However, the difference remained significant $(\mathrm{P}<0.001)$. The univariate differences in readmission $(0.71 ; 0.60$ to $0.84 ; \mathrm{P}<0.001)$, coronary angiography $(0.60 ; 0.47$ to $0.76 ; \mathrm{P}<0.001)$, and revascularisation $(0.69 ; 0.52$ to $0.91 ; \mathrm{P}<0.001)$ were no longer significant after we adjusted for demography.

\section{Comment}

The new criteria identified additional patients who were significantly different from those previously classified as having myocardial infarction in terms of demography, eligiblity for thrombolysis, and outcome. Their poorer survival may be, in part, because they are older and ineligibile for thrombolysis because ST segments are not elevated in electrocardiograms. Less frequent revascularisation may be because of poorer survival but may also reflect real differences in practice. Recent evidence suggests these patients might benefit from early revascularisation. ${ }^{4}$ Thrombolysis rates, 30 day mortality, readmission, and revascularisation are commonly used to assess and compare the quality of care provided by hospitals. Because hospitals vary in both access to troponin assays and adoption of the new diagnostic criteria, ${ }^{5}$ comparisons between hospitals are misleading. Similarly, longitudinal studies will be unable to differentiate between real changes and artefacts. Our findings have serious implications for auditing, benchmarking, and epidemiology.
Kaplan-Meier product limit estimates (95\% confidence intervals) of outcomes after acute myocardial infarction using old ${ }^{*}$ and new ${ }^{\dagger}$ diagnostic criteria

\begin{tabular}{lccc} 
& $\begin{array}{c}\text { Old criteria } \\
\text { (n=1671) }\end{array}$ & $\begin{array}{c}\text { New criteria } \\
\text { additional cases } \\
\text { (n=966) }\end{array}$ & $\begin{array}{c}\text { New criteria total } \\
\text { cases (n=2637) }\end{array}$ \\
\hline Death within 30 days & $19(17$ to 21$)$ & $24(21$ to 27$)$ & 21 (19 to 22) \\
\hline Death within 1 year & $27(25$ to 30$)$ & $45(41$ to 48$)$ & 33 (32 to 35) \\
\hline $\begin{array}{l}\text { Readmission for ischaemic heart disease } \\
\text { within 1 year }\end{array}$ & $38(36$ to 41$)$ & $24(20$ to 27$)$ & 34 (32 to 36) \\
\hline Coronary angiogram within 1 year & $23(21$ to 26$)$ & $13(10$ to 15$)$ & 20 (18 to 22) \\
\hline Coronary revascularisation within 1 year & $14(12$ to 16$)$ & $8(6$ to 10$)$ & 12 (10 to 13) \\
\hline
\end{tabular}

*Based on electrocardiograms, cardiac enzymes, and symptoms.

†Based on troponin concentration and electrocardiograms.

We thank Tom Faichen and Maria Ferguson for providing extracts of data from the laboratory and coronary care unit databases respectively.

Contributors: ACHP had the original concept. ACHP and JPP designed the study. AF and DC linked data from the four sources. AF and JPP did the statistical analyses. JA and ACHP reviewed case notes. JPP wrote the original draft and redraft. ES and JCR contributed data and helped with the methodology. All authors agreed the interpretation and approved the final version. ACHP is guarantor.

Funding: Chief Scientist Office, Department of Health, Scottish Executive (CZG 4240).

Competing interests: None declared.

Record Linkage Department, Information and Statistics Division, Common Services Agency, Edinburgh D Clark senior statistician A Finlayson principal statistician

Correspondence to: A Pell alastair.pell@ laht.scot.nhs.uk

1 World Health Organization Expert Committee. Hypertension and coronary heart disease: classification and criteria for epidemiological studies. Geneva: World Health Organization, 1959. (Technical Report Series No 168.)

2 Hamm CW, Ravkilde J, Gerhardt W, Jorgensen P, Peheim E, Ljungdahl L, et al. The prognostic value of serum troponin $\mathrm{T}$ in unstable angina. $N$ Engl J Med 1992;327:146-50.

3 Joint European Society of Cardiology/American College of Cardiology Committee. Myocardial infarction redefined: a consensus document of the Joint European Society of Cardiology/American College of Cardiology Committee for the Redefinition of Myocardial Infarction. Eur Heart J 2000;21:1502-13.

4 Cannon CP, Weintraub WS, Demopoulos LA, Vicari R, Frey MJ, Lakkis N, et al. Comparison of early invasive and conservative strategies in patients with unstable coronary syndromes treated with the glycoprotein IIb/III a inhibitor tirofiban. N Engl J Med 2001;344:1879-87.

5 Pell ACH, Pell JP. Variations in access to and interpretation of troponin assays are wide. BMJ 2002:324:1216.

(Accepted 5 May 2002)

\section{One hundred years ago}

\section{Medicine and matrimony}

It has been said that marriages would be at least as happy were they made by the Lord Chancellor as they generally prove to be under our present system of sexual selection. Certainly those who know the average French ménage, not as it is pourtrayed by novelists whose sole idea of love is adultery, but as it is seen in quiet provincial towns and in the country, can testify to the happiness of marriages which have been arranged for the contracting parties by their parents or guardians.

There is not, we think, much chance of the Lord Chancellor taking the place of Cupid as a match-maker in this country. It would be well, however, if in negotiations with a view to matrimony the doctor were to be called in as an assessor to the God of Love, who is proverbially blind, and therefore regardless of consequences. It need not be explained in a medical journal how serious the consequences of the marriage of the unfit are likely to be for their offspring, and ultimately for the race. The matter is one of the most far-reaching importance not only to particular nations, but to human society. So strongly has the conviction of this truth impressed itself on social reformers in some foreign countries that, as was stated in a previous article, Bills for the State regulation of marriage have been introduced into the Legislature of several States of the American Union. In North Dakota, the Creed Bill, which became law in 1899, provides that, before a couple can marry, they must obtain a licence which is granted only to such as are able to produce a certificate from a Medical Board stating that they are free from infectious venereal disease, tuberculosis, epilepsy, hereditary insanity, and confirmed inebriety... Now, however, for the first time, as far as we are aware, a European Government has undertaken to deal with the question. At the reopening of the Spanish law courts in Madrid not long ago the Minister of Justice, in speaking of certain reforms which he proposed to introduce, mentioned among these the need for medical sanction of marriage contracts.

(BMJ 1903;i:383) 